Prepared in cooperation with Bureau of Reclamation

\title{
Bull Trout (Salvelinus confluentus) Telemetry and Associated Habitat Data Collected in a Geodatabase from the Upper Boise River, Southwestern Idaho
}

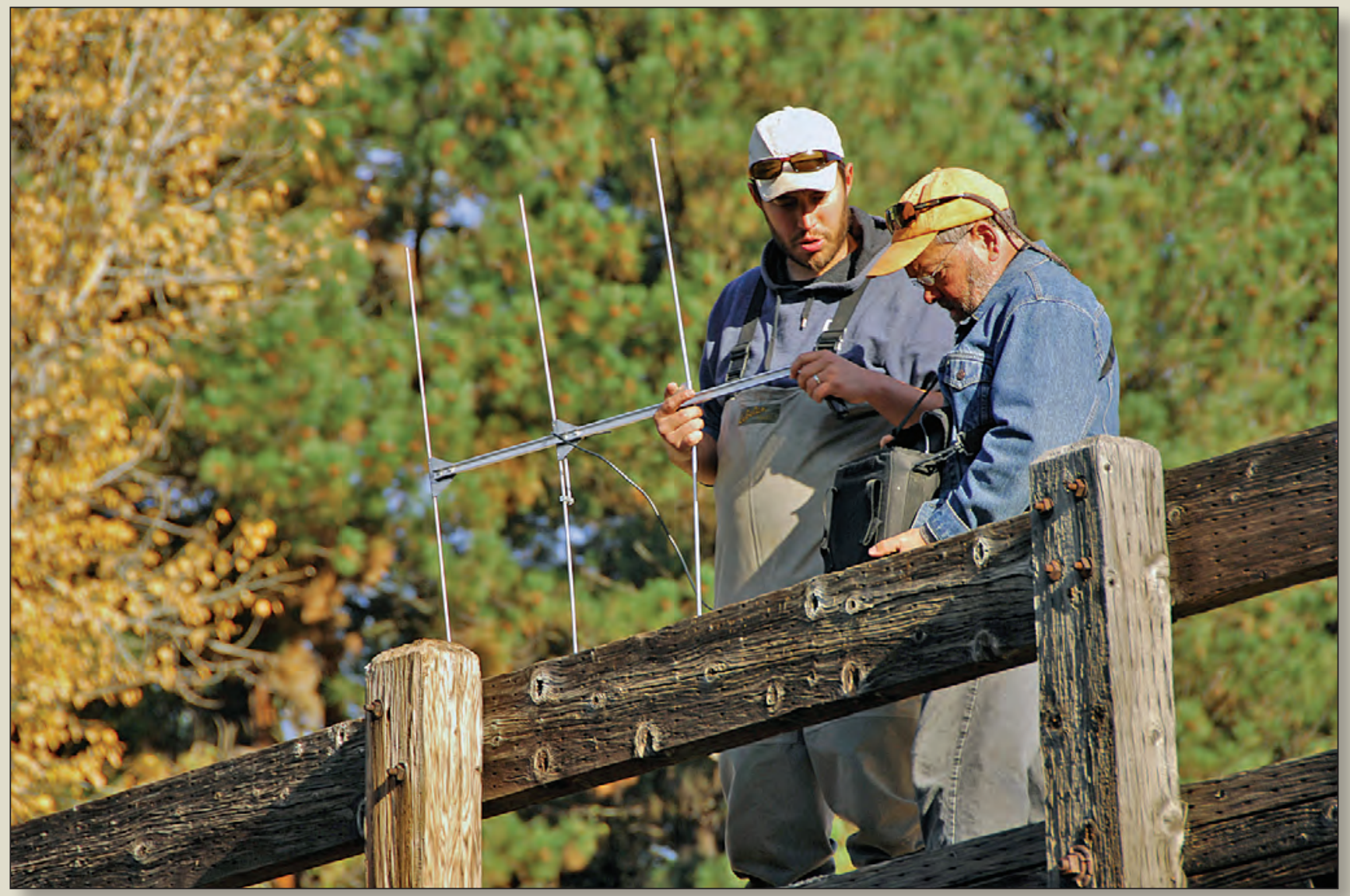

Data Series 1042

U.S. Department of the Interior

U.S. Geological Survey 
Cover: U.S. Geological Survey and Bureau of Reclamation technicians using radio telemetry equipment to document bull trout migration behavior on the North Fork Boise River,

southwestern Idaho. Photograph by Justin Schultz, U.S. Geological Survey, September 2013. 


\section{Bull Trout (Salvelinus confluentus) Telemetry and Associated Habitat Data Collected in a Geodatabase from the Upper Boise River, Southwestern Idaho}

By Dorene E. MacCoy, Zachary M. Shephard, Joseph R. Benjamin,

Dmitri T. Vidergar, and Anthony F. Prisciandaro

Prepared in cooperation with Bureau of Reclamation

Data Series 1042 


\title{
U.S. Department of the Interior \\ RYAN K. ZINKE, Secretary
}

\section{U.S. Geological Survey William H. Werkheiser, Acting Director}

\author{
U.S. Geological Survey, Reston, Virginia: 2017
}

For more information on the USGS - the Federal source for science about the Earth, its natural and living resources, natural hazards, and the environment—visit http://www.usgs.gov or call 1-888-ASK-USGS.

For an overview of USGS information products, including maps, imagery, and publications, visit http://store.usgs.gov.

Any use of trade, firm, or product names is for descriptive purposes only and does not imply endorsement by the U.S. Government.

Although this information product, for the most part, is in the public domain, it also may contain copyrighted materials as noted in the text. Permission to reproduce copyrighted items must be secured from the copyright owner.

Suggested citation:

MacCoy, D.E., Shephard, Z.M., Benjamin, J.R., Vidergar, D.T., and Prisciandaro, A.F., 2017, Bull trout (Salvelinus confluentus) telemetry and associated habitat data collected in a geodatabase from the upper Boise River, southwestern Idaho: U.S. Geological Survey Data Series 1042, 14 p., https://doi.org/10.3133/ds1042.

ISSN 2327-638X (online) 


\section{Contents}

Abstract
Introduction.
Purpose and Scope
Supplemental Data Collection Methods
Fish Data Collection Methods, 2011 .
Geodatabase Design
Data Input
Additional Data Ouality.
Acknowledgments
References Cited.
Appendix A. Descriptions and Sources of Datasets in the Geodatabase for the
Upper Boise River, Southwestern Idaho

\section{Figures}

1. Map showing bull trout telemetry geodatabase study area in the upper Boise River watershed, southwestern Idaho ...............................................................................2

2. Photograph showing bull trout (Salvelinus confluentus) with an archival tag collected from the upper Boise River watershed, southwestern Idaho

\section{Tables}

1. Additional Bureau of Reclamation investigations of bull trout (Salvelinus confluentus) in the upper Boise River, southwestern Idaho

2. Annual and median long term discharge at U.S. Geological Survey streamgages 13185000 and 13190500, upper Boise River watershed, southwestern Idaho, water years 2012-14

3. Stationary telemetry site locations in the upper Boise River watershed, southwestern Idaho, 2011-14..... 


\section{Conversion Factors}

International System of Units to U.S. customary units

\begin{tabular}{lcl}
\hline \multicolumn{1}{c}{ Multiply } & By & \multicolumn{1}{c}{ To obtain } \\
\hline & Length & \\
\hline millimeter $(\mathrm{mm})$ & 0.03937 & inch (in.) \\
meter $(\mathrm{m})$ & 3.281 & foot (ft) \\
kilometer $(\mathrm{km})$ & 0.6214 & mile (mi) \\
\hline & Area & acre \\
\hline hectare $($ ha) & 2.471 & acre \\
square hectometer $\left(\mathrm{hm}^{2}\right)$ & 2.471 & acre \\
square kilometer $\left(\mathrm{km}^{2}\right)$ & 247.1 & square mile $\left(\mathrm{mi}{ }^{2}\right)$ \\
square kilometer $\left(\mathrm{km}^{2}\right)$ & 0.3861 & gallon (gal) \\
\hline & Volume & \\
\hline cubic meter $\left(\mathrm{m}^{3}\right)$ & 264.2 & inch per year $(\mathrm{in} / \mathrm{yr})$ \\
& Flow rate & cubic foot per second (ft $\left.{ }^{3} / \mathrm{s}\right)$ \\
\hline centimeter per year $(\mathrm{cm} / \mathrm{yr})$ & 0.3937 & \\
cubic meter per second $\left(\mathrm{m}^{3} / \mathrm{s}\right)$ & 35.31 & ounce, avoirdupois (oz) \\
\hline
\end{tabular}

Temperature in degrees Celsius $\left({ }^{\circ} \mathrm{C}\right)$ may be converted to degrees Fahrenheit $\left({ }^{\circ} \mathrm{F}\right)$ as

$$
{ }^{\circ} \mathrm{F}=\left(1.8 \times{ }^{\circ} \mathrm{C}\right)+32 .
$$

\section{Datums}

Vertical coordinate information is referenced to the North American Vertical Datum of 1988 (NAVD 88).

Horizontal coordinate information is referenced to the North American Datum of 1983 (NAD 83).

Altitude, as used in this report, refers to distance above the vertical datum. 


\section{Abbreviations}

$\begin{array}{ll}\text { ESRI } & \text { Environmental Systems Research Institute } \\ \text { FGDC-CSDGM } & \text { Federal Geographic Data Committee Content Standard for Digital Geospatial Metadata } \\ \text { FORT } & \text { Fort Collins Science Center } \\ \text { GIS } & \text { geographic information system } \\ \text { GPS } & \text { Global Positioning System } \\ \text { GUIs } & \text { Graphical User Interfaces (GUIs) } \\ \text { IDFG } & \text { Idaho Department of Fish and Game } \\ \text { MFB } & \text { Middle Fork Boise River } \\ \text { NAD } & \text { North American Datum } \\ \text { NRCS } & \text { Natural Resources Conservation Service } \\ \text { Reclamation } & \text { Bureau of Reclamation } \\ \text { SFB } & \text { South Fork Boise River } \\ \text { SNOTEL } & \text { Snow Telemetry } \\ \text { USFWS } & \text { U.S. Fish and Wildlife Service } \\ \text { USGS } & \text { U.S. Geological Survey } \\ \text { WY } & \text { Water Year } \\ \text { XML } & \text { Extensible Markup Language }\end{array}$





\title{
Bull Trout (Salvelinus confluentus) Telemetry and Associated Habitat Data Collected in a Geodatabase from the Upper Boise River, Southwestern Idaho
}

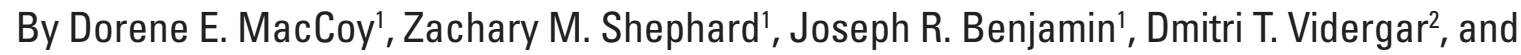 \\ Anthony F. Prisciandaro ${ }^{2}$
}

\begin{abstract}
Bull trout (Salvelinus confluentus), listed as threatened under the Endangered Species Act, are among the more thermally sensitive of coldwater species in North America. The Boise River upstream of Arrowrock Dam in southwestern Idaho (including Arrowrock Reservoir) provides habitat for one of the southernmost populations of bull trout. The presence of the species in Arrowrock Reservoir poses implications for dam and reservoir operations. From 2011 to 2014, the Bureau of Reclamation and the U.S. Geological Survey collected fish telemetry data to improve understanding of bull trout distribution and movement in Arrowrock Reservoir and in the upper Boise River tributaries. The U.S. Geological Survey compiled the telemetry (fish location) data, along with reservoir elevation, river discharge, precipitation, and water-quality data in a geodatabase. The geodatabase includes metadata compliant with Federal Geographic Data Committee content standards. The Bureau of Reclamation plans to incorporate the data in a decision-support tool for reservoir management.
\end{abstract}

\section{Introduction}

Bull trout (Salvelinus confluentus) is a coldwater-adapted species that is listed as threatened throughout the contiguous United States under the Endangered Species Act (U.S. Fish and Wildlife Service, 1999). The decline of the species has been linked to habitat degradation and fragmentation, blockage of migratory corridors, water quality parameters such as increase in water temperature, watershed management practices, and the introduction of non-native species (Rieman and McIntyre, 1993; Rieman and others, 1997; Kanda and others, 2002; Dunham and others, 2003; Kiser and others, 2010). The population of bull trout in the upper Boise River watershed (upper Boise River), in southwestern Idaho, is one of the southernmost distributions in the Columbia River watershed, making them particularly susceptible to the effects of climate change (Rieman and others, 1997; Isaak and others, 2012, 2016). Most of the bull trout population is present in the Arrowrock subwatershed that includes Arrowrock Reservoir and its tributaries - the North Fork, Middle Fork, and South Fork Boise Rivers. Despite the fragmentation of the upper Boise River by the Lucky Peak, Arrowrock, and Anderson Ranch Dams, the watersheds upstream of Arrowrock and Anderson Ranch Reservoirs support substantial habitat for migratory bull trout (Flatter, 1998; Salow and Hostettler, 2004). To prevent future loss to the upper Boise River bull trout population, the Bureau of Reclamation (Reclamation) requested a formal consultation with the U.S. Fish and Wildlife Service (FWS) regarding possible effects on bull trout from operation of the Reclamation Arrowrock and Anderson Ranch projects. The resulting biological opinion (U.S. Fish and Wildlife Service, 2005) listed terms and conditions that may minimize harm to bull trout through operation and maintenance of Arrowrock and Anderson Ranch Reservoirs. To address these terms and conditions, Reclamation, in cooperation with the U.S. Geological Survey (USGS), collected telemetry data between 2011 and 2014 to identify the movement and habitat use of bull trout in the upper Boise River (fig. 1). A file geodatabase was created to store the telemetry and associated habitat data to make it available to Reclamation for future management decisions. Other Reclamation investigations outside the scope of this study but pertinent to future management decisions are presented in table 1.

${ }^{1}$ U.S. Geological Survey.

${ }^{2}$ Bureau of Reclamation. 


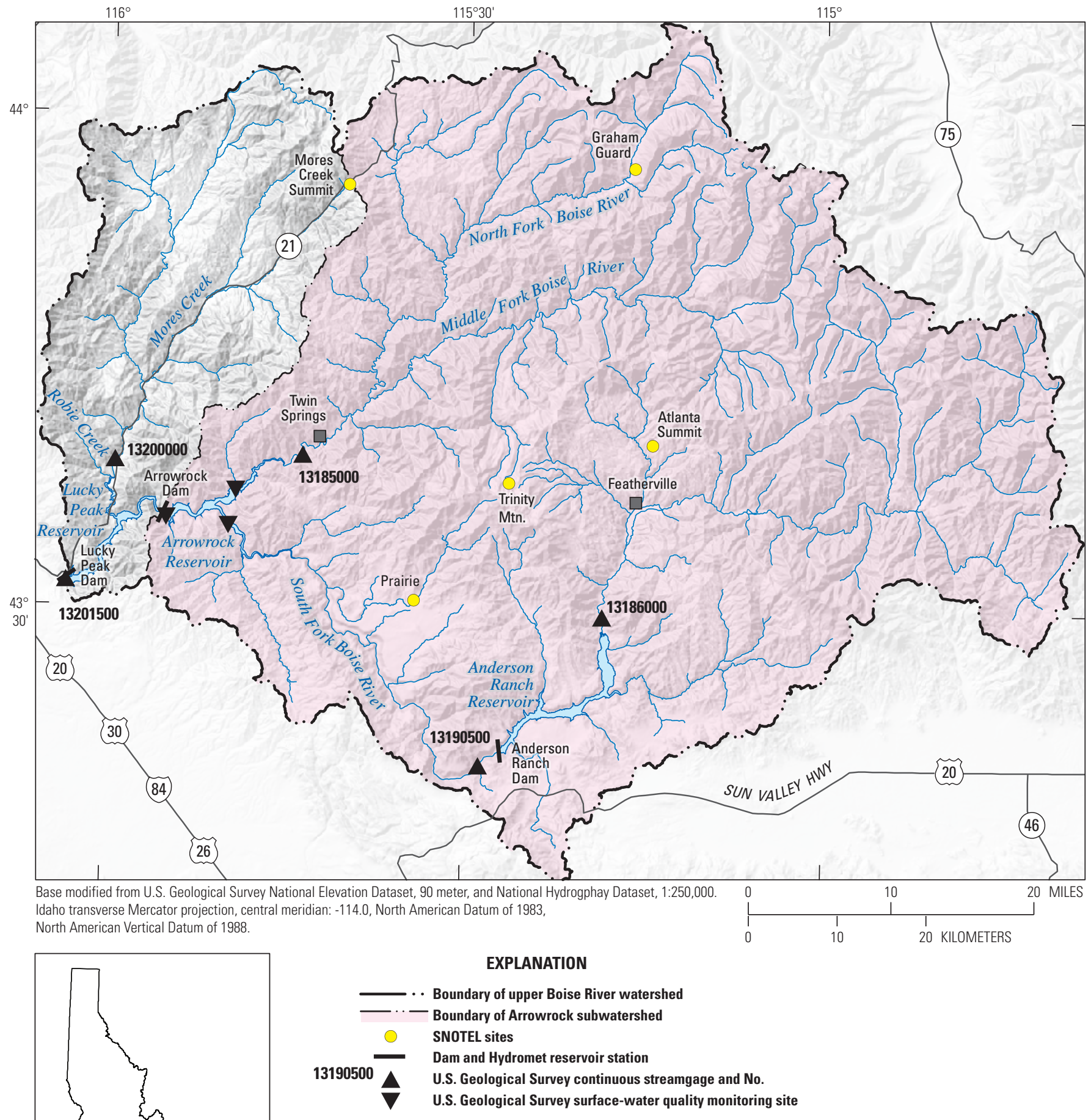

Figure 1. Bull trout telemetry geodatabase study area in the upper Boise River watershed, southwestern Idaho. 
Introduction 3

\begin{tabular}{|c|c|c|c|c|c|}
\hline 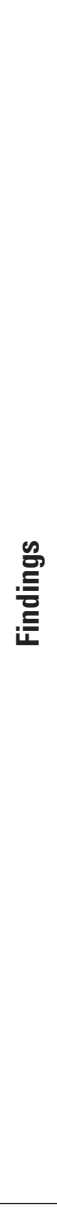 & 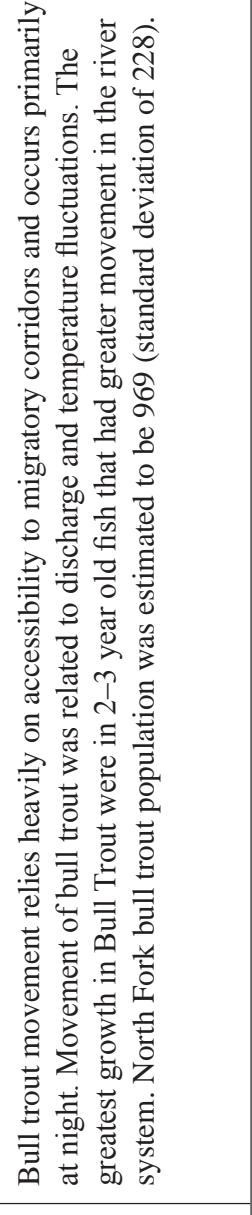 & 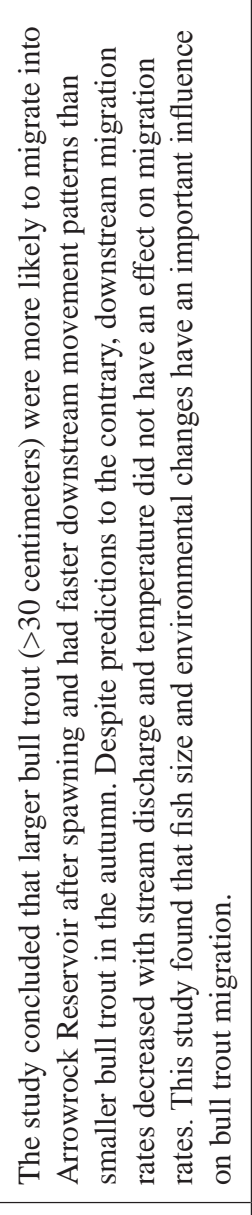 & 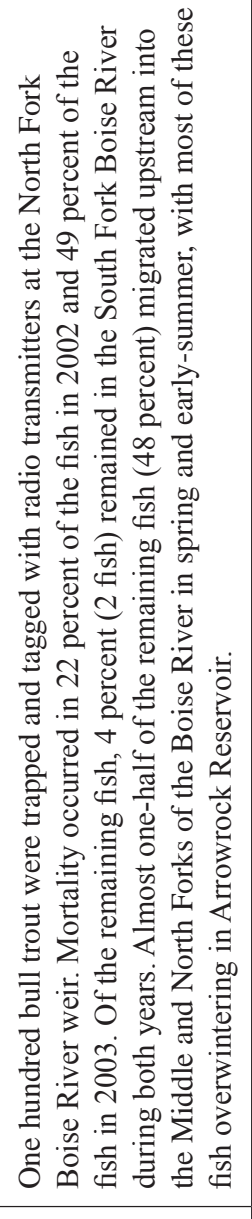 & 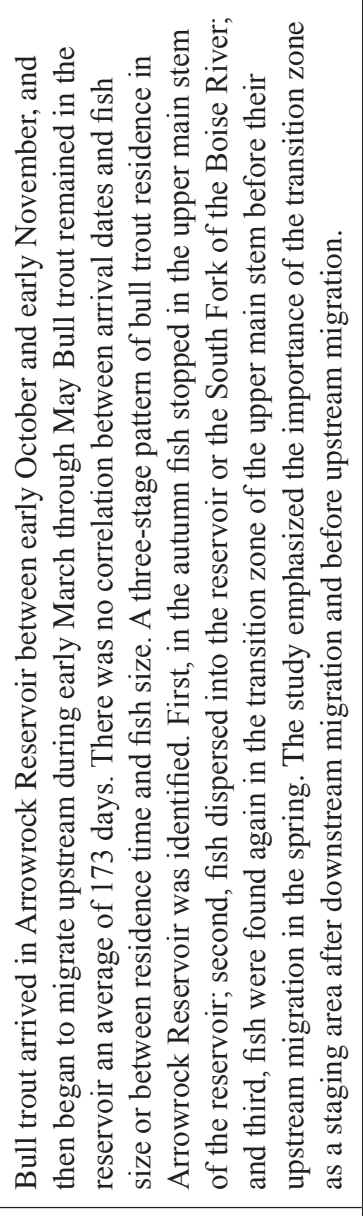 & 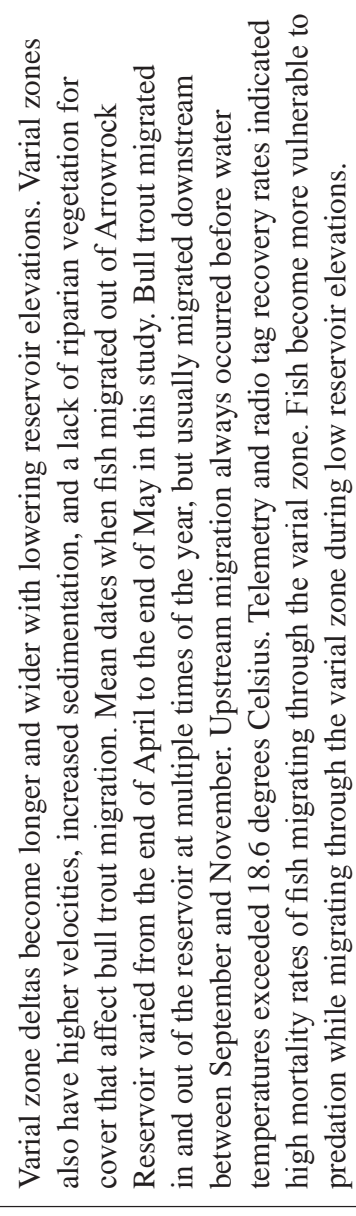 \\
\hline 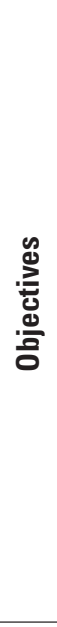 & 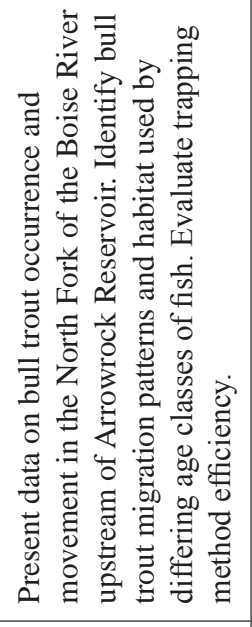 & 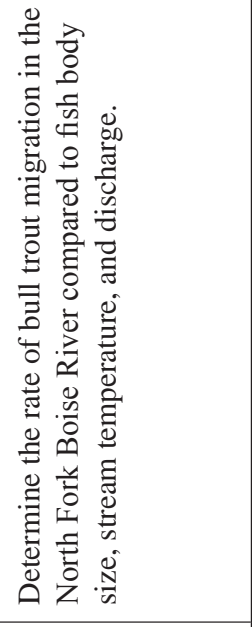 & 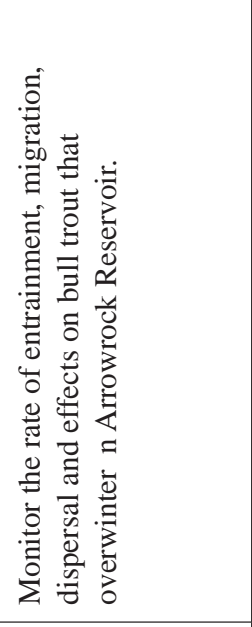 & 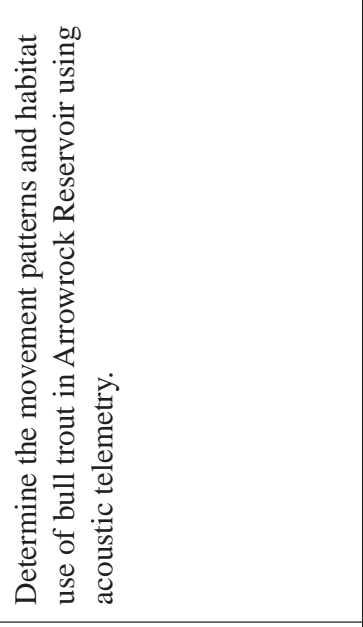 & 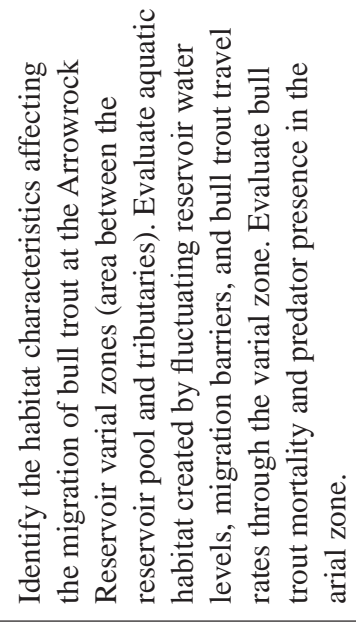 \\
\hline 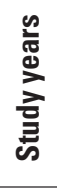 & 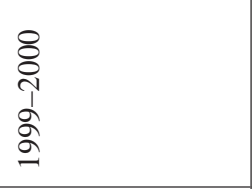 & 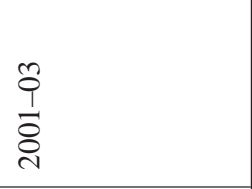 & 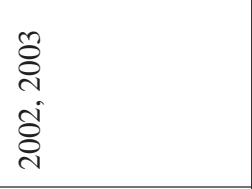 & 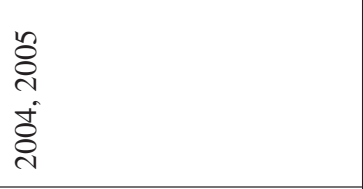 & $\overrightarrow{\mathrm{N}}$ \\
\hline 衣 & 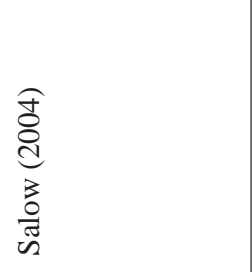 & 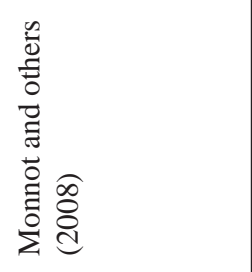 & 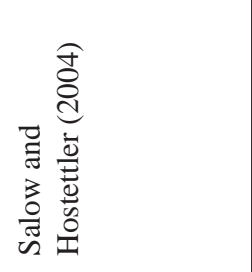 & 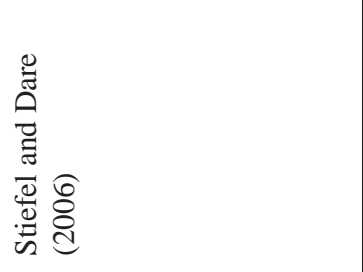 & 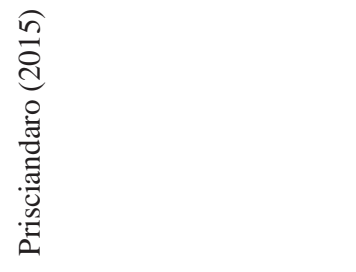 \\
\hline
\end{tabular}




\section{Purpose and Scope}

This report describes the contents of a geodatabase developed to store bull trout telemetry and associated habitat data collected by Reclamation and USGS from the upper Boise River from 2011 to 2014. These data include individual fish information (such as total length and weight) for tagged fish; fish location information collected using radio and acoustic telemetry techniques; and river discharge, reservoir height, and water-quality data where available. Supplemental data such as long-term discharge and snow levels are included in the geodatabase to help in the development of a decision-support tool (these datasets are preceded by an "S" in the geodatabase).

\section{Description of Study Area}

The upper Boise River watershed study area upstream of Lucky Peak Reservoir in southwestern Idaho (fig. 1) is about $5,700 \mathrm{~km}^{2}$, with altitudes ranging from 930 to $3,230 \mathrm{~m}$. The U.S. Forest Service manages most lands in the upper Boise River watershed, with land uses consisting primarily of grazing, timber harvest, mining, and recreation. Climate in the watershed is characterized by cold, wet winters and hot, dry summers with maximum air temperatures commonly exceeding $30^{\circ} \mathrm{C}$. Precipitation commonly ranges from 60 to $100 \mathrm{~cm} / \mathrm{yr}$. High streamflows generally are influenced by snowmelt during spring, with low flows occurring during the rest of the year (McGrath and others, 2001). Three dams on the upper Boise River form Lucky Peak, Arrowrock, and Anderson Ranch Reservoirs in upstream order. These dams and reservoirs are operated collectively as a single system for irrigation, flood control, and recreation. Lucky Peak Dam, at the base of the upper Boise River watershed was constructed by the Corps of Engineers in 1949 and created Lucky Peak
Reservoir. Bull trout are seldom found downstream of the Lucky Peak Dam but Reclamation continues to monitor Lucky Peak Reservoir and tributaries to insure bull trout have not passed through the dam. Arrowrock Dam, the oldest of these dams, was constructed in 1915 and is managed by Reclamation. The full pool altitude of Arrowrock Reservoir is $980 \mathrm{~m}$, covering $1,275 \mathrm{ha}$, with a pool volume of about $3.36 \times 10^{8} \mathrm{~m}^{3}$ and maximum depth of about $60 \mathrm{~m}$. Arrowrock Reservoir, a narrow canyon reservoir, is highly regulated, with about 86 percent of its volume typically released annually, which equates to a low water-level altitude of about $945 \mathrm{~m}$ (Bureau of Reclamation, 2016). Two major tributaries, the Middle Fork Boise River (MFB) and South Fork Boise River (SFB), form the two arms of Arrowrock Reservoir. The MFB is unregulated, whereas the SFB is regulated downstream of Anderson Ranch Dam, and is free-flowing for about $43.5 \mathrm{~km}$ before it enters Arrowrock Reservoir. Discharge is measured on the MFB at the Boise River near Twin Springs, Idaho (USGS streamgage 13185000) with more than 100 years of record, and on the SFB at South Fork Boise River at Anderson Ranch Dam, Idaho (USGS streamgage 13190500), with more than 70 years of record. Discharge during water years (WYs) 2012-2014 varied between the MFB and SFB. Annual discharge for both MFB and SFB was greater than the long-term median in WY 2012 and less than long-term median in WY 2013 (table 2). Water year 2014 discharge was greater than long-term median for the MFB and less than long-term median for SFB. The transition from these two large tributaries to the lentic waters of Arrowrock Reservoir are where bull trout are commonly found (Stiefel and Dare, 2006). Based on studies by Flatter (1998) and Salow and Hostettler (2004), discharge and water temperatures in these major tributaries are important factors contributing to the migration behavior of bull trout in this system.

Table 2. Annual and median long-term discharge at U.S. Geological Survey streamgages 13185000 and 13190500, upper Boise River watershed, southwestern Idaho, water years 2012-14.

[Discharge data from U.S. Geological Survey (2016). Abbreviations m³/s, cubic meter per second; MFB, middle fork Boise River; SFB, South Fork Boise River]

\begin{tabular}{|c|c|c|c|c|c|c|}
\hline \multirow[t]{2}{*}{ Station name } & \multirow[t]{2}{*}{ Short name } & \multirow[t]{2}{*}{ Station No. } & \multicolumn{3}{|c|}{$\begin{array}{l}\text { Average annual discharge } \\
\qquad\left(\mathrm{m}^{3} / \mathrm{s}\right)\end{array}$} & \multirow{2}{*}{$\begin{array}{l}\text { Long-term median } \\
\text { discharge } \\
\left(\mathrm{m}^{3} / \mathrm{s}\right)\end{array}$} \\
\hline & & & 2012 & 2013 & 2014 & \\
\hline Boise River near Twin Springs & MFB & 13185000 & 42 & 26 & 35 & 33 \\
\hline South Fork Boise River at Anderson Ranch Dam & SFB & 13190500 & 35 & 21 & 17 & 24 \\
\hline
\end{tabular}




\section{Supplemental Data Collection Methods}

Reservoir height data were retrieved from the Reclamation Hydromet system from Hydromet reservoir stations Arrowrock Dam and Reservoir (ARK), Anderson Ranch Dam and Reservoir (AND), and Lucky Peak Lake near Boise (LUC) (Bureau of Reclamation, 2016). Hydromet stations collect data at intervals of 15-60 minutes and transmit the data by the Geostationary Operational Environmental Satellite (GOES) network every 4 hours. Data are then processed by the local Reclamation area office and posted on the Hydromet Web site.

Discharge data were retrieved from USGS National Water Information System (NWIS) streamgages (U.S. Geological Survey, 2016) for Boise River near Twin Springs, South Fork Boise River at Anderson Ranch Dam, South Fork Boise River near Featherville (13186000), Mores Creek above Robie Creek, near Arrowrock Dam (13200000), and South Fork Boise River at Neal Bridge, near Arrowrock Dam (13192200). All discharge data included in the geodatabase are provisional and subject to change.

Precipitation and snow level data were retrieved from the Natural Resources Conservation Service (NRCS) Snow Telemetry (SNOTEL) database for Mores Creek Summit, Graham Guard, Atlanta Summit, Trinity Mountain, and Prairie. Information on SNOTEL data collection and processing is available at the NRCS Web site (http://www.wcc.nrcs.usda. gov/snow/index.html).

\section{Fish Data Collection Methods, 2011-14}

Fish were sampled in Arrowrock Reservoir using a random grid sampling design and mark-recapture methods for estimating fish populations. A 366-m-long gill net with
0.04-0.1 $\mathrm{m}$ mesh was used to capture the fish between March 28 and April 20, 2012. Fish species other than bull trout were counted and measured where possible. These data are provided in untagged fish datasets. Captured bull trout were anesthetized using a portable electronacrosis system similar to the one used by Hudson and others (2011). When the fish were immobilized, they were measured for fork and total length (in millimeters) and mass (in grams). Uniquely coded passive integrated transponder (PIT) tags were injected just beneath and behind the dorsal fin of each bull trout. A subset of fish were fitted with radio and (or) archival tags using a modified shielded needle technique described by Ross and Kleiner (1982). Archival tags (fig. 2) were set to record internal temperature of the fish, water temperature at the fish location, and water pressure (depth) at the fish location at 30-minute intervals. Data from archival tags were downloaded when fish were recaptured and the tags were removed. Archival tag data were examined using methods similar to those used in Howell and others (2010).

Radio-tagged fish were tracked between 2011 and 2014 twice a month on the ground using Lotek SRX models 400 and 600 receivers during October-March of 2011-14 while the fish were in the SFB or Arrowrock Reservoir. Additional tracking was completed during reservoir ramping and at more frequent intervals during the study period. When a radio-tagged fish was located, the following data were recorded at that location: (1) date, (2) time, (3) Global Positioning System (GPS) location, (4) pressure (water depth), and (5) water temperature at the location of the fish. Three stationary telemetry stations equipped with Lotek SRX model 600 receivers (operating continuously) were established at USGS streamgage sites, Boise River near Twin Springs and South Fork Boise River at Neal Bridge, near Arrowrock Dam, and a site used by Reclamation for detection of entrained fish downstream of Arrowrock Dam (table 3).

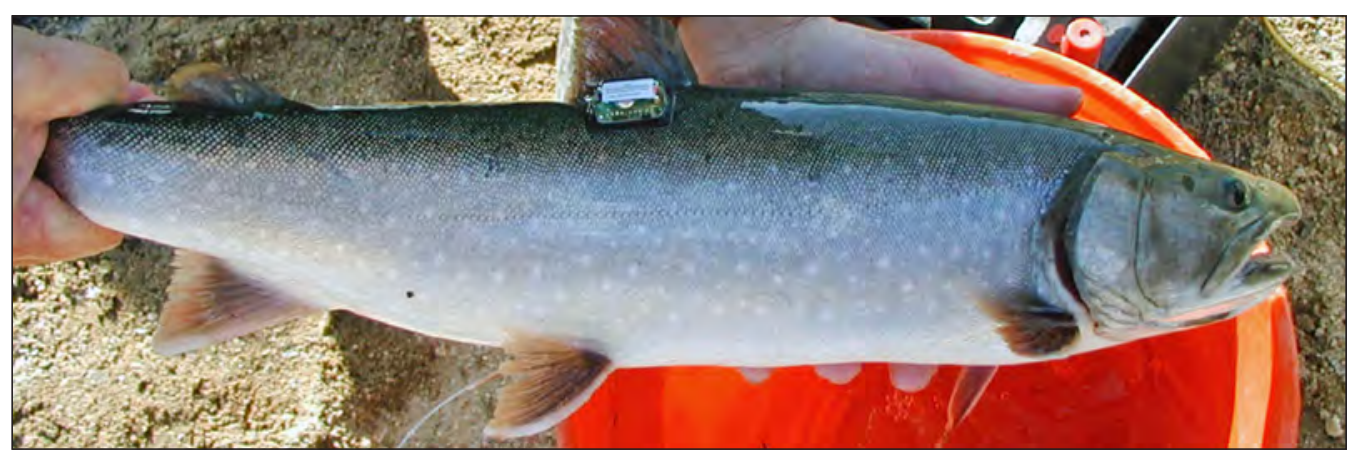

Figure 2. Bull trout (Salvelinus confluentus) with an archival tag collected from the upper Boise River watershed, southwestern Idaho. (Photograph by Dimitri Vidergar, Bureau of Reclamation, September 2013.) 
Table 3. Stationary telemetry site locations in the upper Boise River watershed, southwestern Idaho, 2011-14.

[Abbreviation: USGS, U.S. Geological Survey]

\begin{tabular}{lccc}
\hline \multicolumn{1}{c}{ Site description } & USGS site ID & Latitude & Longitude \\
\hline South Fork Boise River at Neal Bridge, near Arrowrock Dam & 13192200 & 43.550 & -115.719 \\
Boise River near Twin Springs & 13185000 & 43.668 & -115.725 \\
Below Arrowrock Dam in Lucky Peak Reservoir & - & 43.597 & -115.925 \\
\hline
\end{tabular}

Acoustic tracking in Arrowrock Reservoir was done using a boat mounted GPS device that recorded fish locations. A Lotek MAP 600 RT receiver with two hydrophones mounted at $0.5 \mathrm{~m}$ below the water surface on the port and starboard bow of the boat were used to record and detect acoustic signals during tracking events. A stationary LOTEK submersible acoustic receiver (model WHS3250) was placed in each of the three locations in the reservoir (referred to as strata) from May 7 to September 5, 2012, to record fish movements by stationary sites. Mobile and stationary site acoustic telemetry data as well as water-quality profile data collected in Arrowrock Reservoir during 2012 are published in Maret and Schultz (2013).

\section{Geodatabase Design}

A file geodatabase was developed using Environmental Systems Research Institute (Esri) geographic information system (GIS) software ArcGISTM 10.3.1 for storage of bull trout telemetry and associated habitat data. This spatially enabled database allows users to store and manipulate tabular and geospatial datasets. The geodatabase contains nine tabular datasets with geographically referenced discharge, reservoir height, and climatological data; and as many as 20 point, line, and polygon vector datasets stored as feature classes. Feature classes with common themes are grouped and stored together as feature datasets. These themes include the geographic location of fish, basin layers, hydrography, water quality, and continuous data collection site locations. Raster datasets are included that contain bathymetric and topography data. Additionally, relationship classes were established between dataset attribute tables using a common date field to aid in querying the data. Descriptions and sources of datasets contained in the upper Boise River geodatabase are presented in appendix A. The geodatabase and associated metadata are available in MacCoy and others (2017).

\section{Data Input}

Data fields were removed or added to the raw data to reduce redundancy or for data clarification. Some of the raw data contained repeating fields that were removed. A unique fish identification number was added to each tagged fish because some radio tags were reused in different fish.
Unique identification numbers are a combination of the tag code and the three digits following the decimal point of the tag frequency.

Spatial data were provided by Reclamation, and shapefiles were directly uploaded to the geodatabase. Spatial data were projected from their native coordinate systems into the projected coordinate system North American Datum of 1983 Idaho Transverse Mercator projection (NAD 83 Idaho TM). Some spatial datasets in the geodatabase are partial or clipped versions of their original data source. The content of the original datasets was not modified except to "snap" telemetered fish locations to the Boise River. A detailed description of this technique is discussed in section, "Data Quality." All tabular data were converted to shapefiles prior to uploading to the geodatabase.

\section{Data Quality}

The original mobile tracking data points represented the location of the radio receiver at the time a fish was detected. Most mobile tracking efforts occurred along a road next to the reservoir or river. The radio receivers on land were assumed to record detections perpendicular to the actual location of the fish in the stream or reservoir. Therefore, points representing fish detections were snapped to a line feature class in the adjacent waterbody. These snapped points are included in the telemetry data in the geodatabase (appendix A, BoiseArea_Telemetry_2011_2014). However, coordinates listed in the attributes table for this dataset are the original unsnapped coordinates. Furthermore, detections of fish using mobile tracking were done from a motor vehicle and were not confirmed visually.

\section{Metadata}

Metadata compliant with the Federal Geographic Data Committee Content Standard for Digital Geospatial Metadata (FGDC-CSDGM) were created for each spatial and tabular dataset in the file geodatabase. Associated metadata in this report provide descriptive information about each feature class, raster, and table in the geodatabase and include components such as a title, abstract, purpose, and citation information. Metadata also include information such as the data creation and process steps, geographic settings, and attribute descriptions. A detailed listing of FGDC-CSDGM 
content is available at http://www.fgdc.gov/metadata/ geospatial-metadata-standards (Federal Geographic Data Committee, 2014).

Metadata were created and validated for FGDC-CSDGM format using Metadata Wizard version: 1.5, a tool developed by the USGS Fort Collins Science Center (FORT), to simplify metadata creation and formatting for GIS users. Two graphical user interfaces (GUIs) were used to enter additional or missing metadata information. Metadata were validated using the Metadata Parser and information exported out of the wizard in an FGDC-CSDGM compliant eXtensible Markup Language (XML) metadata record (Ignizio and others, 2014). The metadata XML files associated with this database often were modified after the Metadata Wizard exported the files; however, all data were validated with the Metadata Parser after editing.

\section{Additional Data}

The database structure allows additional data to be incorporated as it becomes available. For example, collection of discharge and temperature data would be ongoing and can be included in the database, as well as updated versions of linked datasets such as the Bull Trout Vulnerability Assessment database (Dunham, 2015). Additional datasets are available that could inform a decision-support modeling effort, but were beyond the scope of this report and database. These existing datasets may include, but are not limited to:

- Fish stocking records that may provide information on available prey for migratory bull trout (Idaho Department of Fish and Game, 2016),

- Infrared flight data to estimate temperature in the upper Boise River (Quantum Spatial, Incorporated, 2014; Dmitri Vidergar, Bureau of Reclamation, written commun., January 3, 2017), and

- Additional studies on bull trout in the Boise River and reservoirs (for example, Flatter, 1998).

Finally, other modeling efforts, such as the Reclamation water-quality model for Arrowrock and Anderson Ranch Reservoirs, may be beneficial to a decision-support model, and can be included upon completion.

\section{Acknowledgments}

The authors thank the following individuals who helped collect and process data for this study: Shawna Castle, Afton Dixon, Ryan Hedrick, Tony Parra, and Trevor Watson from the Bureau of Reclamation; Terry Maret and Justin Schultz from the U.S. Geological Survey; and several personnel from the Idaho Department of Fish and Game.

\section{References Cited}

Bureau of Reclamation, 2016, Hydromet historical data access: Hydromet network, Northwest Region, Bureau of Reclamation Web site, accessed July 16, 2016, at https:// www.usbr.gov/pn/hydromet/arcread.html.

Dunham, J., Reiman, B., and Chandler, G., 2003, Influences of temperature and environmental variables on the distribution of bull trout within streams at the southern margin of its range: North American Journal of Fisheries Management, v. 23, p. 894-904.

Dunham, J.B., 2015, Rangewide climate vulnerability assessment for threatened bull trout: Final Report to Northwest Climate Science Center, p. 1-47, accessed November 28, 2016, at http://fresc.usgs.gov/products/ ProductDetails.aspx?ProductNumber=60209.

Federal Geographic Data Committee, 2014, Geospatial metadata standards: Federal Geographic Data Committee, accessed April 7, 2016, at http://www.fgdc.gov/metadata/ geospatial-metadata-standards.

Flatter, Brian, 1998, Life history and population status of migratory bull trout (Salvelinus confluentus) in Arrowrock Reservoir, Idaho: Prepared for the Bureau of Reclamation, Cooperative Agreement Number 1425-6FC-10-02170, Idaho Department of Fish and Game, Boise, Idaho, 81 p.

Howell, P.J., Dunham J.B., and Sankovich, P.M., 2010, Relationships between water temperatures and upstream migration, cold water refuge use, and spawning of adult bull trout from the Lostine River, Oregon, USA: Ecology of Freshwater Fish, v. 19, p. 96-106.

Hudson, J.M., Johnson, J.R., and Kynard, B., 2011, A portable electronarcosis system for anesthetizing salmonids and other fish: North American Journal of Fisheries Management, v. 31, p. 335-339.

Idaho Department of Fish and Game, 2016, Idaho fishing planner, historical stocking records: Idaho Department of Fish and Game database, accessed March 14, 2017, at https://fishandgame.idaho.gov/ifwis/fishingPlanner/ stocking/?region=8,3\&stock=16.

Ignizio, D.A., O’Donnell, M.S., and Talbert, C.B., 2014, Metadata wizard-An easy-to-use tool for creating FGDCCSDGM metadata for geospatial datasets in ESRI ArcGIS Desktop: U.S. Geological Survey Open-File Report, 2014-1132, 14 p., accessed March 30, 2016, at http://dx.doi. org/10.3133/ofr20141132.

Isaak, D.J., Wollrab, S., Horan, D., and Chandler, G., 2012, Climate change effects on stream and river temperatures across the northwest U.S. from 1980-2009 and implications for salmonid fishes: Climate Change, v. 113, p. 499-524. 
Isaak, D.J., Young, M.K., Luce, C.H., Hostetler, S.W., Wenger, S.J., Peterson, E.E., Ver Hoef, J.M., Groce, M.C., Horan, D.L., and Nagel, D.E., 2016, Slow climate velocities of mountain streams portend their role as refugia for coldwater biodiversity: Proceedings of the National Academy of Sciences, v. 113, p. 4,374-4,379.

Kanda, N., Leary, R.F., and Allendorf, F.W., 2002, Evidence of introgressive hybridization between bull trout and brook trout: Transactions of the American Fisheries Society, v. 131, p. 772-782.

Kiser, T., Hansen, J., and Kennedy, B., 2010, Impacts and pathways of mine contaminants to bull trout (Salvelinus confluentus) in an Idaho watershed: Archives of Environmental Contamination and Toxicology, v. 59, no. 2, p. 301-311.

MacCoy, D.E., Shephard, Z.M., Benjamin, J.R., Vidergar, Dmitri, and Prisciandaro, Anthony, 2017, Bull trout (Salvelinus confluentus) telemetry and associated habitat data collected in a geodatabase from the Upper Boise River, Southwestern Idaho: U.S. Geological Survey data release, https://doi.org/10.5066/F7MG7MQJ.

Maret, T.R., and Schultz, J.E., 2013, Bull trout (Salvelinus confluentus) movement in relation to water temperature, season, and habitat features in Arrowrock Reservoir, Idaho, 2012: U.S. Geological Survey Scientific Investigations Report 2013-5158, 28 p., http://pubs.usgs.gov/ sir/2013/5158/.

McGrath, C.L., Woods, A.J., Omernik, J.M., Bryce, S.A., Edmondson, M., Nesser, J.A., Shelden, J., Crawford, R.C., Comstock, J.A., and Plocher, M.D., 2001, Ecoregions of Idaho (color poster with map, descriptive text, summary tables, and photographs): U.S. Geological Survey (map scale 1:1,350,000), accessed August 17, 2016, at https:// archive.epa.gov/wed/ecoregions/web/html/id_eco.html.

Monnot, L., Dunham, J.B., Hoem, T., and Koesier, P., 2008, Influences of body size and environmental factors on autumn downstream migration of bull trout in the Boise River, Idaho: North American Journal of Fisheries Management, v. 28, p. 231-240.

Prisciandaro, A.F., 2015, Interactions between fluctuating reservoir water levels and bull trout (Salvelinus confluentus) ecology: University of Idaho, M.S. thesis, 162 p., accessed August 17, 2016, at http://gradworks.umi. com/15/88/1588420.html.

Quantum Spatial, Incorporated, 2014, Boise River, IdahoThermal infrared imagery technical data report: Portland, Oregon, Quantum Spatial, Incorporated, 24 p.
Rieman, B.E., Lee, D.C., and Thurow, R.F., 1997, Distribution, status, and likely future trends of bull trout within the Columbia River and Klamath River Basins: North American Journal of Fisheries Management, v. 17, no. 4, p. 1,111-1,125.

Rieman, B.E., and McIntyre, J.D., 1993, Demographic and habitat requirements for conservation of bull trout: U.S. Forest Service General Technician Report INT-302, 42 p., accessed August 17, 2016, at http://www.fs.fed.us/rm/pubs_ int/int_gtr302.pdf.

Ross, M.J., and Kleiner, C.F., 1982, Shielded-needle technique for surgically implanting radio-frequency transmitters in fish: The Progressive Fish-Culturist, v. 44, p. 41-43.

Salow, T., 2004, Population structure and movement patterns of adfluvial bull trout (Salvelinus confluentus) in the North Fork Boise River Basin, Idaho: Bureau of Reclamation Technical Report for the Upper Snake River Biological Opinion Number 1009.2700, 120 p., accessed August 17, 2016, at http://www.usbr.gov/pn/snakeriver/esa/bulltrout/ reports/thesis-bulltrout-northforkboise.pdf.

Salow, T., and Hostettler, L., 2004, Movement and mortality patterns of adult adfluvial bull trout (Salvelinus confluentus) in the Boise River Basin Idaho-Interim summary report for the Arrowrock Dam valve replacement project: Technical Report for Arrowrock Dam Biological Opinion Number 1009.0405 OALS Number 00-912 and Upper Snake River Biological Opinion Number 1009.2700, 40 p., accessed August 17, 2016, at http://www.usbr.gov/pn/snakeriver/esa/ bulltrout/reports/2004-Arrowrockvalveradiotelemetry.pdf.

Stiefel, C.B., and Dare, M.R., 2006, Movements and habitat use by adfluvial bull trout in Arrowrock Reservoir, Idaho: Bureau of Reclamation, Project Completion Report for Agreement 1425-03-FC-10-9440, 49 p.

U.S. Fish and Wildlife Service, 1999, Determination of threatened status of bull trout in the coterminous United States: Federal Register, v. 64, no. 201, p. 58,909-58,933, accessed July 18, 2016, at http://www.fws.gov/policy/ frsystem/title.cfm?title=Endangered $\% 20$ and $\% 20$ threatened $\% 20$ species $\& d o c$ type $=$ final $\&$ date $=99$.

U.S. Fish and Wildlife Service, 2005, Biological opinion for Bureau of Reclamation operations and maintenance in the Snake River Basin above Brownlee Reservoir: U.S. Fish and Wildlife Service, accessed July 19, 2016, at https://www.fws.gov/idaho/documents/BOs/05_F_0532_ BORUpperSnake.pdf.

U.S. Geological Survey, 2016, USGS surface-water data for the nation: National Water Information System-Web interface, accessed March 8, 2016, at http://waterdata.usgs. gov/nwis/sw. 


\title{
Appendix A. Descriptions and Sources of Datasets in the Geodatabase for the Upper Boise River, Southwestern Idaho
}

\author{
Dataset: S_SNO_Atlanta \\ Desaription: Snow Telemetry (SNOTEL) data for Atlanta Summit site, Boise River Basin, Idaho [S_SNO_Atlanta] \\ Source Downloaded from Natural Resources Conservation Service (NRCS) Interactive Map. Link: http://www.wcc.nrcs.usda. \\ gov/webmap/help/index.html \\ SNOTEL site link: http://wcc.sc.egov.usda.gov/nwcc/site?sitenum=306 \\ Data Processing: Data retrieved in tabular format in January 2016. Data formatted as needed including the reordering of various \\ columns. Data exported to file geodatabase as a GDB table using ArcMap ${ }^{\mathrm{TM}}$ 10.3.1 export option.
}

DateRange: 10/01/1997-9/30/2000 and 10/1/2010-9/30/2014

Dataset: S_SNO_GrahamGuard

Desaription: SNOTEL Data for Graham Guard site, Boise River Basin, Idaho [S_SNO_GrahamGuard]

Source: Downloaded from NRCS Interactive Map. Link: http://www.wcc.nrcs.usda.gov/webmap/help/index.html

SNOTEL site link: http://wcc.sc.egov.usda.gov/nwcc/site?sitenum=496

Data Processing: Data retrieved in tabular format in January 2016. Data formatted as needed including the reordering of various columns. Data exported to file geodatabase as a GDB table using ArcMap ${ }^{\mathrm{TM}}$ 10.3.1 export option.

DateRange: 10/01/1997-9/30/2000 and 10/1/2010-9/30/2014

Dataset: S_SNO_Mores

Desaription: SNOTEL data for Mores Creek Summit site, Boise River Basin, Idaho [S_SNO_Mores]

Source: Downloaded from National Resources Conservation Service (NRCS) Interactive Map. Link: http://www.wcc.nrcs.usda. gov/webmap/help/index.html

SNOTEL site link: http://wcc.sc.egov.usda.gov/nwcc/site?sitenum=637

Data Processinge Data retrieved in tabular format in January 2016. Data formatted as needed including the reordering of various columns. Data exported to file geodatabase as a GDB table using ArcMap ${ }^{\text {TM }}$ 10.3.1 export option.

DateRange: 10/01/1997-9/30/2000 and 10/1/2010-9/30/2014

Dataset: S_SNO_Prairie

Desaription: SNOTEL data for Prairie site, Boise River Basin, Idaho [S_SNO_Prairie]

Source: Downloaded from NRCS Interactive Map. Link: http://www.wcc.nrcs.usda.gov/webmap/help/index.html

SNOTEL site link: http://wcc.sc.egov.usda.gov/nwcc/site?sitenum=704

Data Processing: Data retrieved in tabular format in January 2016. Data formatted as needed including the reordering of various columns. Data exported to file geodatabase as a GDB table using ArcMap ${ }^{\mathrm{TM}}$ 10.3.1 export option.

DateRange: 10/01/1997-9/30/2000 and 10/1/2010-9/30/2014

Dataset: S_SNO_TrinityMtn

Desaription: SNOTEL data for Trinity Mountain site, Boise River Basin, Idaho [S_SNO_TrinityMtn]

Source: Downloaded from NRCS Interactive Map. Link: http://www.wcc.nrcs.usda.gov/webmap/help/index.html

SNOTEL site link: http://wcc.sc.egov.usda.gov/nwcc/site?sitenum=830

Data Processing Data retrieved in tabular format in January 2016. Data formatted as needed including the reordering of various columns. Data exported to file geodatabase as a GDB table using ArcMap ${ }^{\mathrm{TM}}$ 10.3.1 export option.

DateRange: 10/01/1997-9/30/2000 and 10/1/2010-9/30/2014

Dataset: arrowrock_bathy_10ft

Desaription: 10-foot contour interval bathymetry of Arrowrock Reservoir in Idaho, result of 1987 and 1997 Bureau of Reclamation (Reclamation) surveys [arrowrock_bathy_10ft]

Source: Reclamation

Data Processing: Data originally created by Reclamation. Data transferred to U.S. Geological Survey (USGS) on an external hard drive in January 2016. Data exported to file geodatabase feature dataset as a feature class with coordinate system NAD_1983_Idaho_TM using $\operatorname{ArcMap}^{\text {TM }}$ 10.3.1 export option. Data shifted 90 feet west and 195 feet south, as suggested by the original Reclamation metadata.

DateRange: 10/1987-06/1997 
Dataset arrowrock_bathy_50ft

Description: 50-ft contour interval bathymetry of Arrowrock Reservoir in Idaho, result of 1987 and 1997 Reclamation surveys [arrowrock_bathy_50ft]

Source Reclamation

Data Processing. Data originally created by Reclamation. Data transferred to USGS on an external hard drive in January 2016. Data exported to file geodatabase feature dataset as a feature class with coordinate system NAD_1983_Idaho_TM using ArcMap $^{\mathrm{TM}}$ 10.3.1 export option. Data shifted 90 feet west and 195 feet south, as suggested by the original metadata.

DateRange: 10/1987-06/1997

Dataset Land_Use

Description: Ownership polygon features for Boise National Forest [Land_Use]

Source Boise National Forest

Data Processing: Data originally created by the U.S. Department of Agriculture Forest Service ALP/GIS Lab. Given to USGS through personal communication from the Bureau of Reclamation. Data were retrieved in January 2016. Data exported to file geodatabase feature dataset as a feature class with coordinate system NAD_1983_Idaho_TM using ArcMap ${ }^{\mathrm{TM}}$ 10.3.1 export option.

DateRange 11/18/2004

Dataset Stratum_All

Description: All three Reclamation strata in Arrowrock Reservoir near Boise, Idaho, created for Bull Trout Telemetry Studies [Stratum_All]

Source: Reclamation

Data Processing Data originally created by Reclamation. Data transferred to USGS on an external hard drive in January

2016. Data exported to file geodatabase feature dataset as a feature class with coordinate system NAD_1983_Idaho_TM using ArcMap $^{\mathrm{TM}}$ 10.3.1 export option.

DateRange Current ground condition

Dataset boiseriver_dams

Description: Current dams of the upper Boise River Basin [boiseriver_dams]

Source USGS

Data Processing Relevant dams clipped from larger USGS shapefile containing dams located throughout the US (citation in database metadata), creating layer from selection, and then exported to file geodatabase feature dataset as a feature class with coordinate system NAD_1983_Idaho_TM using ArcMap ${ }^{\mathrm{TM}}$ 10.3.1 export option.

DateRange: Current ground condition

Dataset boisearea_SNOTELSites

Description: SNOTEL sites of the upper Boise River Basin, Plotted NRCS data coordinates [boisearea_SNOTELSites] Source: NRCS

Data Processing: Created by typing the SNOTEL site latitudes and longitudes (collected from NRCS) into Microsoft Excel ${ }^{\circledR}$, then displaying the X, Y. Data exported to file geodatabase feature dataset as a feature class with coordinate system NAD_1983_ Idaho_TM using ArcMap ${ }^{\mathrm{TM}}$ 10.3.1 export option.

DateRange Current ground condition

Dataset boisearea_gages

Description: USGS streamgages of the upper Boise River Basin [boisearea_gages]

Source USGS

Data Processing Relevant gaging sites clipped from source file (citation in database metadata) using the ArcMap ${ }^{\mathrm{TM}} 10.3 .1$ clip tool. Data exported to file geodatabase feature dataset as a feature class with coordinate system NAD_1983_Idaho_TM using $\operatorname{ArcMap}^{\mathrm{TM}}$ 10.3.1 export option.

DateRange: Current ground condition 
Dataset: ANDWatershed

Desaription: USGS StreamStats - Anderson Ranch Dam pour point drainage basin characteristics [ANDWatershed]

Source: USGS StreamStats (Version 3.0). Link: http://water.usgs.gov/osw/streamstats/

Data Processing: To delineate the watershed, "watershed delineation from a point" tool applied at the desired pour point in USGS StreamStats (Version 3.0). Data downloaded as a shapefile and exported to file geodatabase feature dataset as a feature class with coordinate system NAD_1983_Idaho_TM using ArcMap ${ }^{\mathrm{TM}}$ 10.3.1 export option.

DateRange: Basin and characteristics are representative of the current ground state

Dataset: ARKWatershed

Desaription: USGS StreamStats - Arrowrock Dam pour point drainage basin characteristics [ARKWatershed]

Source: USGS StreamStats (Version 3.0). Link: http://water.usgs.gov/osw/streamstats/

Data Processing Collected and downloaded from USGS StreamStats (Version 3.0) in January 2016. To delineate the watershed, "watershed delineation from a point" tool applied at the desired pour point. Data downloaded as a shapefile and exported to file geodatabase feature dataset as a feature class with coordinate system NAD_1983_Idaho_TM using ArcMap ${ }^{\text {TM }}$ 10.3.1 export option.

DateRange: Basin and characteristics are representative of the current ground state.

Dataset: BTVA_Boise_Patches

Description: Bull Trout Vulnerability Assessment patches, upper Boise River [BTVA_Boise_Patches]

Source: Stream patches of suitable bull trout habitat and associated patch variables. Link: https://www.sciencebase.gov/catalog/ item/54494685e4b0f888a81bb4d9

Data Processing Data originally created by the USGS Forest and Rangeland Ecosystem Science Center (FRESC).

Data received and reformatted in March 2016. Data exported to file geodatabase and projected to coordinate system

NAD_1983_Idaho_TM.

DateRange: 1984-2011(range of data used in data model patches)

Note: modeled results are continually updated, refer to FRESC website link for current version.

Dataset: LPWatershed

Desaription: USGS StreamStats - Lucky Peak Dam pour point drainage basin characteristics [LPWatershed]

Source: USGS StreamStats (Version 3.0). Link: http://water.usgs.gov/osw/streamstats/

Data Processing Collected and downloaded from USGS StreamStats (Version 3.0) in January 2016. To delineate the watershed, "watershed delineation from a point" tool applied at the desired pour point. Data downloaded as a shapefile and exported to file geodatabase feature dataset as a feature class with coordinate system NAD_1983_Idaho_TM using ArcMap ${ }^{\mathrm{TM}}$ 10.3.1 export option.

DateRange: Basin and characteristics are representative of the current ground state.

Dataset: boiseriver_reservoirs

Desaription: 1:250,000 scale reservoir polygons - Lucky Peak, Arrowrock, Anderson Ranch only [boiseriver_reservoirs] Source: Idaho Department of Water Resources. Link: http://www.idwr.idaho.gov/GIS/NHD/

Data Processing Reservoirs needed for this dataset selected from the original shapefile using ArcMap ${ }^{\mathrm{TM}}$ 10.3.1, and a new layer temporarily created from the selection (however, temporary layer never saved as a layer file). New layer then exported to file geodatabase feature dataset as a feature class with coordinate system NAD_1983_Idaho_TM using ArcMap ${ }^{\text {TM }}$ 10.3.1 export option.

DateRange: Represents the ground state in 1996.

Dataset: Initial Capture

Description: Reclamation bull trout telemetry initial capture, 2011-13, Boise River Basin - Arrowrock Reservoir [Initial_Capture]

Source: Reclamation

Data Processinge Data originally created by Reclamation. Data transferred to USGS on an external hard drive in January 2016. Data retrieved from Microsoft Excel ${ }^{\circledR}$ files and then formatted into a shapefile / GDB from displaying xy coordinates. Data exported to file geodatabase feature dataset as a feature class with coordinate system NAD_1983_Idaho_TM using ArcMap ${ }^{\mathrm{TM}}$ 10.3.1 export option.

DateRange: 09/18/2011-10/21/2013 
Dataset Recapture

Description: Reclamation bull trout telemetry recapture, 2011-13, Boise River Basin - Arrowrock Reservoir [Recapture]

Source Reclamation

Data Processing: Data originally created by Reclamation. Data transferred to USGS on an external hard drive in January 2016. Data were retrieved from Microsoft Excel ${ }^{\circledR}$ files and then formatted into a shapefile / GDB from displaying xy coordinates. Data exported to file geodatabase feature dataset as a feature class with coordinate system NAD_1983_Idaho_TM using ArcMap ${ }^{\mathrm{TM}}$ 10.3.1 export option.

DateRange: 09/07/2011-10/21/2013

Dataset bathy10ftdem

Description: Arrowrock Reservoir - Boise River Basin, Idaho - 10-m (meter) bathymetry converted from contours to raster [bathy10ftdem]

Source Reclamation

Data Processing Data originally created by Reclamation. Data transferred to USGS on an external hard drive in January 2016. Data converted from a polyline vector dataset to a raster dataset using ArcMap ${ }^{\mathrm{TM}}$ 10.3.1 Polyline to Raster (Conversion) tool. Data exported to file geodatabase feature dataset with coordinate system NAD_1983_Idaho_TM using ArcMap ${ }^{\mathrm{TM}}$ 10.3.1 export option. Data shifted 90 feet west and 195 feet south, as suggested by the original metadata.

Date Range: 10/1987-06/1997

Dataset bathy50ftdem

Description: Arrowrock Reservoir - Boise River Basin, Idaho—-50-m bathymetry converted from contours to raster [bathy50ftdem]

Source Reclamation

Data Processing Data converted from a polyline vector dataset to a raster dataset using ArcMap $^{\mathrm{TM}}$ 10.3.1 Polyline to Raster (Conversion) tool. Data exported to file geodatabase with coordinate system NAD_1983_Idaho_TM using ArcMap ${ }^{\text {TM }}$ 10.3.1 export option. Data shifted 90 feet west and 195 feet south, as suggested by the original metadata.

Date Range: 10/1987-06/1997

Dataset boisebasin90mrelief

Description: 90-m resolution Digital Elevation Map (DEM) of central and southern Idaho, collected from Elevation Derivative for National Applications (EDNA) [boisebasin90mrelief]

Source EDNA, derived from the National Elevation Dataset (NED).

Data Processing The 90-m resolution DEM was made from EDNA. Shaded relief was generated using default values, but a z factor of 0.01.Data exported to a file geodatabase and projected into coordinate system NAD_1983_Idaho_TM using ArcMap ${ }^{\mathrm{TM}}$ 10.3.1 export option. Data was shifted 90 feet west and 195 feet south, as suggested by the original metadata.

DateRange 2002

Dataset idaho90rlfclp

Description: Idaho 90-m shaded relief, clipped to the spatial extent of the upper Boise River Basin, derived from EDNA shaded relief [idaho90rlfclp]

Source EDNA, derived from the NED.

Data Processing EDNA 90-m shaded relief clipped to Boise Basin extent using ArcMap ${ }^{\mathrm{TM}}$ 10.3.1 clip tool. Basin extent determined by delineating the Lucky Peak drainage basin with StreamStats Version 3.0. Exported to file geodatabase with coordinate system NAD_1983_Idaho_TM using the export option in $\operatorname{ArcMap}^{\mathrm{TM}}$ version 10.3.1.

DateRange 2002

Dataset S_Rsvr_Lvls

Description: Boise River Basin Reservoir Hydromet storage data for water years 1998-2000, 2011-14 [S_Rsvr_Lvls]

Source Reclamation Hydromet. Link: http://www.usbr.gov/pn/hydromet/

Data Processing Data retrieved in tabular format in January 2016. Data reformatted as needed, including reordering of various columns. Additional columns added with the calculated change in active storage for each reservoir relative to the previous day. Data exported to file geodatabase as a file geodatabase table using ArcMap ${ }^{\mathrm{TM}}$ 10.3.1 export option.

DateRange: 10/01/1997-9/30/2000 and 10/1/2010-9/30/2014 
Dataset: S_Rvr_Q

Description: Discharge data from streamgages in the upper Boise River Basin, for water years 1998-2000, 2011-14 [S_Rvr_Q] Source USGS National Water Information System (NWIS) Web Interface. Link: http://waterdata.usgs.gov/id/nwis/ current/?agency_cd=usgs\&parameter_cd=staname,datetime,00065,00060,00010,median\&group_key=basin_cd

Data Processing: Data for individual sites downloaded from USGS NWIS. Data from each site collected individually in tabular form, then compiled in one spreadsheet. Table exported to file geodatabase as a GDB table using ArcMap ${ }^{\text {TM }}$ 10.3.1 export option. DateRange: 10/01/1997-9/30/2000 and 10/1/2010-9/30/2014

Dataset: ARK_Acoustic_2012

Description: USGS 2012 bull trout acoustic tag telemetry tracking, Arrowrock fish mobile and stationary receiver telemetry studies [ARK_Acoustic_2012]

Source USGS (Maret and Schultz, 2013)

Data Processinge. Data retrieved in tabular format in February 2016 from Microsoft Excel ${ }^{\circledR}$ file. Data imported to ArcMap $^{\mathrm{TM}}$ 10.3.1 and formatted into a shapefile from displaying xy coordinates (latitude and longitude). Data exported to file geodatabase

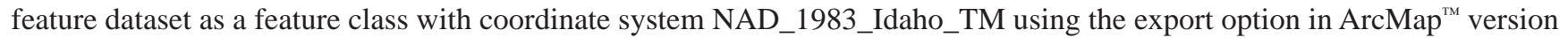
10.3.1. Additional columns added to the attribute table, and reorganization of the table occurred as needed.

Date Range: 04/10/2012-08/21/2012

Dataset: S_AND_IDFG_1998_2000

Desaription: Idaho Department of Fish and Game (IDFG) bull trout radio tag telemetry, South Fork Boise River, 1998-99 [S_AND_IDFG_1998_2000]

Source IDFG (Partridge and others, 2001). Data in this study collected using fixed-winged aircraft. Because of distance of plane above the ground and speed of travel, accuracy recorded probably within 0.5 kilometer. If a fish located near the confluence of two streams, both streams indicated by an overlapping object.

Data Processing Data received by Reclamation in a shapefile and provided to the USGS. Data exported to file geodatabase feature dataset as a feature class with coordinate system NAD_1983_Idaho_TM using the export option in $\operatorname{ArcMap}^{\mathrm{TM}}$ version $^{\text {. }}$ 10.3.1

DateRange: 03/19/1998-05/18/2000

Dataset: BoiseArea_Telemetry_2011_2014

Desaription: Bull trout radio tracking from stationary sites at South Fork Boise River at Neal Bridge near Arrowrock Dam, Boise River near Twin Springs, and Reclamation site below Arrowrock dam in Lucky Peak Reservoir, and mobile tracking.

Source: Reclamation Data Processing Data originally created by Reclamation in tabular format Microsoft Excel ${ }^{\circledR}$ file. Data imported to ArcMap ${ }^{\mathrm{TM}}$ 10.3.1. Additional field "Unique_ID" added. A subset of the original stationary site data was created to reduce detection redundancy. The original stationary site data contained multiple detections of fish movement within antennae range. The multiple detections of each fish were consolidated into one stationary site detection.

DateRange: 01/03/2012-02/13/2014

Dataset: WQ_LP_Dam_Site

Description: Water-quality profile near Arrowrock Dam, from 2012 USGS telemetry studies [WQ_LP_Dam_Site] Source: USGS (Maret and Schultz 2013)

Data Processing: Data extracted from appendix A in Maret and Schultz (2013) and then formatted into a shapefile by using ArcGIS $^{\mathrm{TM}}$ 10.3.1 Add XY Coordinates tool. Data exported to file geodatabase feature dataset as a feature class with coordinate system NAD_1983_Idaho_TM using the export option in ArcMap ${ }^{\mathrm{TM}}$ version 10.3.1. Additional columns added (such as latitude and longitude) to the attribute table, and table fields reorganized as needed.

DateRange: 02/19/2012-10/04/2012 
Dataset WQ_Middle_Fork_Arm

Description: Water-quality profile in Arrowrock Reservoir near the Middle Fork Arm, from 2012 USGS telemetry studies [WQ_Middle_Fork_Arm]

Source USGS (Maret and Schultz 2013)

Data Processing: Data extracted from appendix A in Maret and Schultz (2013) and then formatted into a shapefile by using ArcGIS $^{\mathrm{TM}}$ 10.3.1 Add XY Coordinates tool. Data exported to file geodatabase feature dataset as a feature class with coordinate system NAD_1983_Idaho_TM using the export option in ArcMap ${ }^{\mathrm{TM}}$ version 10.3.1. Additional columns added (such as latitude and longitude) to the attribute table, and table fields reorganized as needed. Water-quality parameters measured with a Hydrolab DS5 meter starting at $1 \mathrm{~m}$ below the surface and then at 2-m increments to $21 \mathrm{~m}$ below the water surface. Below this depth, measurements taken every $5 \mathrm{~m}$ until the bottom reached.

DateRange: 05/19/2012 -10/04/2012

Dataset WQ_South_Fork_Arm

Description: Water-quality profile in Arrowrock Reservoir near the South Fork Arm, from 2012 USGS telemetry studies [WQ_South_Fork_Arm]

Source USGS (Maret and Schultz 2013)

Data Processing: Data extracted from appendix A in Maret and Schultz (2013) and then formatted into a shapefile by using ArcGIS $^{\text {TM }}$ 10.3.1 Add XY Coordinates tool. Data exported to file geodatabase feature dataset as a feature class with coordinate system NAD_1983_Idaho_TM using the export option in ArcMap $^{\mathrm{TM}}$ version 10.3.1. Additional columns added (such as latitude and longitude) to the attribute table, and table fields reorganized as needed. Water-quality parameters measured with a Hydrolab DS5 meter starting at $1 \mathrm{~m}$ below the surface and then at 2-m increments to $21 \mathrm{~m}$ below the water surface. Below this depth, measurements taken every $5 \mathrm{~m}$ until the bottom reached.

DateRange: 05/19/2012 -10/04/2012

Dataset untagged_fish

Description: Untagged fish from 2011 to 2014 telemetry sampling efforts, upper Boise River [untagged_fish]

Source USGS

Data Processing Developed by Dorene MacCoy of the USGS. Data compiled from several fish capture and telemetry data sources provided by Reclamation in March 2016. Table exported to file geodatabase as a GDB table using ArcMap ${ }^{\text {TM }}$ 10.3.1 export option.

DateRange: 08/31/2011-11/02/2012

Dataset untagged_fish_location

Description: Untagged fish location, upper Boise River telemetry sampling, 2011-14 [untagged_fish_location]

Source USGS

Data Processing Developed by Dorene MacCoy of the USGS. Data compiled from several fish capture and telemetry data sources provided by Reclamation in March 2016. Table exported to file geodatabase

DateRange: 10/24/2011-11/02/2012

Dataset Acoustic stationary sites

Description: Three sites located within Arrowrock Reservoir

Source: USGS as a GDB table using ArcMap ${ }^{\mathrm{TM}}$ 10.3.1 export option.

Data Processing Data table containing site coordinates imported to ArcMap 10.3.1. The Add XY Coordinates tool was used to create temporary spatial layer. Layer then exported to file geodatabase feature dataset as a feature class with coordinate system NAD_1983_Idaho_TM using the export option in ArcGIS version 10.3.1.

DateRange: 04/10/2012 - 08/21/2012

Dataset Telemetered stationary sites

Description: USGS streamgage locations at Boise River near Twin Springs and South Fork Boise River at Neal Bridge near Arrowrock Dam, Idaho, and a site used by Reclamation for detection of entrained fish below Arrowrock Dam

Source Reclamation

Data Processing Data table containing site coordinates imported to ArcMap 10.3.1. The Add XY Coordinates tool was used to create temporary spatial layer. Layer then exported to file geodatabase feature dataset as a feature class with coordinate system NAD_1983_Idaho_TM using the export option in ArcGIS version 10.3.1.

DateRange: 01/03/2012-02/13/2014 
Publishing support provided by the U.S. Geological Survey Science Publishing Network, Tacoma Publishing Service Center

For more information concerning the research in this report, contact the Director, Idaho Water Science Center

U.S. Geological Survey

230 Collins Road

Boise, Idaho 83702

http://id.water.usgs.gov 
묭

홓

홍

홍

言

듬

땀.

高 